Огляди літератури, оригінальні дослідження, погляд на проблему, випадок з практики, короткі повідомлення УДК 616.281-06:612.825.2-053.82

DOI 10.11603/1811-2471.2019.v.i4.10791

\title{
ВПЛИВ ВЕСТИБУЛЯРНОГО НАВАНТАЖЕННЯ НА ПСИХОМОТОРНІ ОСОБЛИВОСТІ МОЛОДИХ ОСІБ
}

\author{
Тернопільський національний медичний університет імені І. Я. Горбачевського МОз України
}

РЕзЮмЕ. Психомоторні реакції та складні інтегративні взаємодії рухових ядер центральної нервової системи відіграють значну роль у забезпеченні рухової діяльності. Тому злагодженість і впорядкованість рухів у часі й просторі широко вивчаються у психофізіології, фізіології спорту та фізіології праці. Це обумовлює надзвичайну важливість подальшого вивчення особливостей психомоторних показників в умовах подразнення вестибулярного аналізатора в осіб з підвищеною вестибулярною чутливістю.

Мета - цінити вплив вестибулярного навантаження на психомоторні особливості осіб з підвищеною чутливістю вестибулярного аналізатора.

Матеріал і методи. Вестибулярну чутливість визначали за допомогою анкетування. Психомоторні показники визначали за допомогою комп'ютерної системи «Діагност-1М» в режимі «теппінг-тесту» до та після вестибулярного навантаження. Обертальну пробу проводили на кріслі Барані. Оцінку сили нервових процесів проводили за класифікацією, запропонованою Е. П. Ільїним.

Результати. Нами встановлено, що особи, як з належною, так і з підвищеною вестибулярною чутливістю, мали середньо-сильну, середню та середньо-слабку нервові системи, однак, серед осіб із підвищеною чутливістю у 44 \% випадків спостерігали середньо-слабку нервову систему. У них після вестибулярного навантаження максимальний темп руху кисті прямолінійно направлений на зниження. Оскільки методика теппінг-тесту має важливе значення в діагностиці функціонального стану центральної нервової системи, а наші результати виявляють ознаки фізичної втоми в осіб із підвищеною вестибулярною чутливістю під впливом вестибулярного навантаження, то це $\epsilon$ важливою основою для подальшої профілактики та корекції відповідних станів, а саме, для вибору оптимальних навантажень для таких осіб.

Висновки. У стані спокою відмінності психомоторних показників відображають відмінності в силі нервової системи. Аналіз сили нервових процесів в осіб із підвищеною чутливістю вестибулярного аналізатора показав, що значне зниження працездатності спостерігається в другій половині тесту.

КлючОвІ СлОВА: психомоторні реакції; сила нервових процесів; підвищена чутливість; вестибулярний аналізатор.

Вступ. Психомоторні реакції-поліструктурна функціональна система, яка відіграє значну роль у забезпеченні рухової діяльності [1]. Тому злагодженість і впорядкованість рухів у часі й просторі широко вивчаються у психофізіології, фізіології спорту та фізіології праці. За допомогою виявлення рівня розвитку цих реакцій можна характеризувати силу нервової системи, спортивну кваліфікацію та професійну приналежність осіб. Підвищена напруженість, збудливість та чутливість аналізаторів здійснюють не тільки фізичний, але і психічний вплив на організм. Нейродинамічні показники і психофізіологічний стан $\epsilon$ першим і чутливим індикатором змін, що відбуваються в організмі й істотно впливають на роботу всіх фізіологічних систем. У процесі рухової активності значного навантаження зазнають сенсорні системи, а саме вестибулярна, адже основне їі значення - підтримка вертикального положення та забезпечення координації рухів. 3 нервово-психічним розвитком тісно пов'язаний розвиток і стан моторики, в зв'язку з чим інтенсивне функціонування рухового аналізатора створює передумови для активної діяльності центральної нервової системи [2]. Саме тому багато робіт присвячені дослідженню впливу вестибулярної стійкості на рівень техніко-тактичної підготовленості баскетболістів та волейболістів [3-6].

Таким чином, необхідно відзначити надзвичайну важливість подальшого вивчення особливостей психомоторних показників в умовах подразнення вестибулярного аналізатора в осіб з підвищеною вестибулярною чутливістю.

Мета - оцінити вплив вестибулярного навантаження на психомоторні особливості осіб з підвищеною чутливістю вестибулярного аналізатора.

Матеріал і методи дослідження. В обстеженні взяли участь 60 осіб. Вестибулярну чутливість визначали за допомогою анкетування [7]. За допомогою комп'ютерної системи «Діагност-1М» в режимі теппінг-тесту визначали психомоторні особливості до та після вестибулярного навантаження [5]. Обертальну пробу проводили на кріслі Барані [4].

Метод теппінг-тесту ґрунтується на реєстрації змін у часі максимального темпу рухів кисті та дозволяє оцінити функціональні можливості рухового аналізатора, а також силу процесу збудження і рухливості основних нервових процесів. Оцінку сили нервових процесів проводили за класифікацією, запропонованою Е. П. Ільїним. Згідно з нею, 
Огляди літератури, оригінальні дослідження, погляд на проблему, випадок з практики, короткі повідомлення виокремили такі типи кривих: опуклий, який характеризує сильну нервову систему, рівний - середню, низхідний - слабку, увігнутий - середньосильну, проміжний - середньо-слабку [5].

Статистичне опрацювання даних проводили методом непараметричної статистики, визначаючи Т-критерій Вілкоксона.

Результати й обговорення. Після проведення анкетування ми поділили осіб на дві групи. До першої групи увійшли 30 осіб, у яких ми виявили належну вестибулярну чутливість; до другої - 30 осіб із підвищеною вестибулярною чутливістю. За результатами теппінг-тесту ми поділили обстежуваних залежно від сили нервової системи (рис. 1).

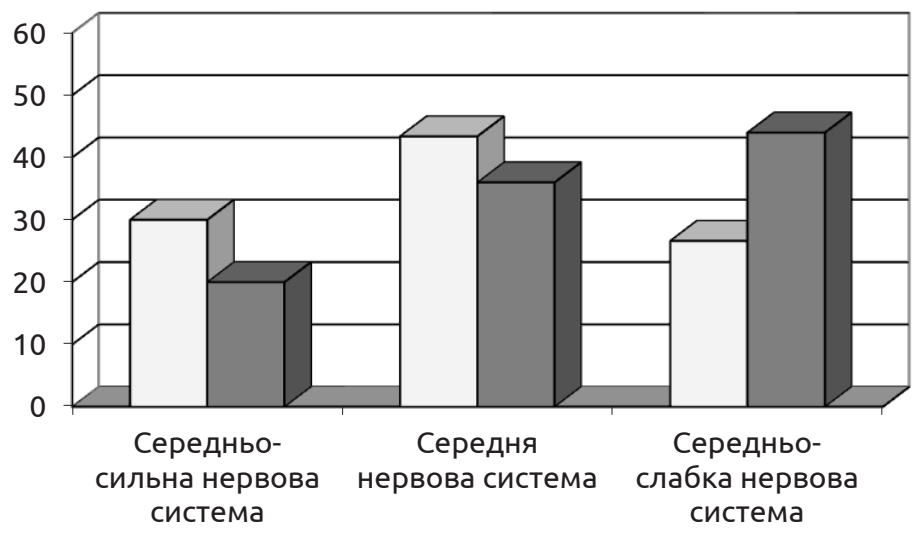

口Належна чутливість

口Підвищена чутливість

Рис. 1. Розподіл обстежуваних в залежності від сили нервової системи (за результатами теппінг-тесту) та вестибулярної чутливості (\%).

Ми встановили, що особи як з належною, так і з підвищеною вестибулярною чутливістю, мали середньо-сильну, середню та середньо-слабку нервові системи. Однак, у 43,4 \% осіб з належною чутливістю вестибулярного аналізатора ми спостерігали середню силу нервової системи, а у осіб із підвищеною чутливістю - у 44 \% випадків середньо-слабку нервову систему (рис. 1). Особи із середньо-сильною нервовою системою переважали серед осіб із належною вестибулярною чутливістю - 30 \%, порівняно із підвищеною - 20 \%; із середньо-слабкою нервовою системою переважали особи із підвищеною вестибулярною чутливістю - 44 \%, порівняно із належною - 26,6\%.

Психомоторні показники в осіб з належною вестибулярною чутливістю після вестибулярного навантаження змінювались наступним чином (рис. 2):

- в осіб із середньо-сильною нервовою системою достовірно знизились на 5 секунді тесту $(p<0,05)$, але на 15 секунді достовірно підвищились $(p<0,05)$;

- в осіб із середньою та середньо-слабкою нервовими системами показники достовірно знизились на 5 та 15 секундах тесту $(p<0,05)$.

Психомоторні показники в осіб з підвищеною вестибулярною чутливістю після вестибулярного навантаження змінювались наступним чином (рис. 3):

- в осіб із середньо-сильною нервовою системою достовірно знизились на 10, 20, 25 та 30 секундах тесту $(p<0,05)$;
- в осіб із середньою нервовою системою зниження показників відбувалось протягом усього тесту $(p<0,05)$;

- в осіб із середньо-слабкою нервовою системою показники достовірно знижувались з 10 до 30 секунд тесту $(p<0,05)$.

Динаміка показників рухів кисті до та після вестибулярного навантаження за даними теппінгтесту в групі з належною вестибулярною чутливістю у стані після вестибулярного навантаження була нижчою на 15 секунді, порівняно з вихідним станом $(p<0,05)$ (рис. 4).

3 даних, наведених на рисунку 4, видно, що в них темп руху кисті в кінці проходження теппінгтесту на фоні вестибулярного навантаження був направлений на зростання.

У студентів із підвищеною вестибулярною чутливістю показники руху кисті у стані спокою знижувались впродовж періоду з 10 до 30 секунд $(p<0,05)$. Порівнюючи вказаний показник на початку та в кінці тесту можна зробити висновок про достовірне зниження здатності підтримувати максимальний темп руху кисті руки у даної групи обстежуваних. Із даних рисунка 4 видно, що у них частота рухів після вестибулярного навантаження прямолінійно направлена на зниження $(p<0,05)$.

Відмінності психомоторних показників у стані спокою між групами залежно від вестибулярної чутливості вказують на переважання осіб із середньо-слабкою нервовою системою серед осіб із підвищеною вестибулярною чутливістю, тому що у них упродовж перших 10-15 секунд тесту темп ру- 
Огляди літератури, оригінальні дослідження, погляд на проблему, випадок з практики, короткі повідомлення

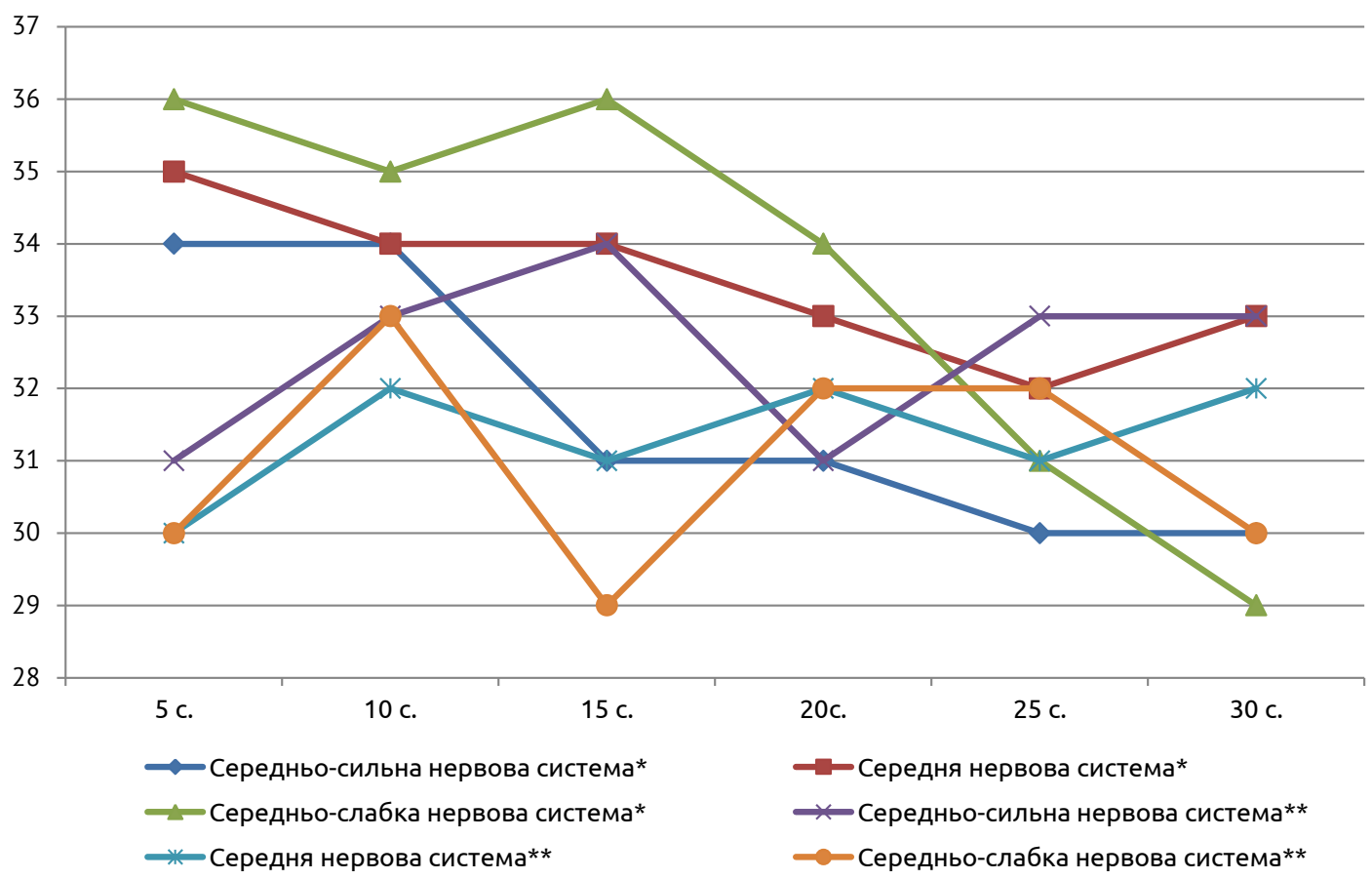

Рис. 2. Психомоторні показники в осіб з належною вестибулярною чутливістю до та після вестибулярного навантаження.

Примітка. * - до навантаження, ** - після навантаження.

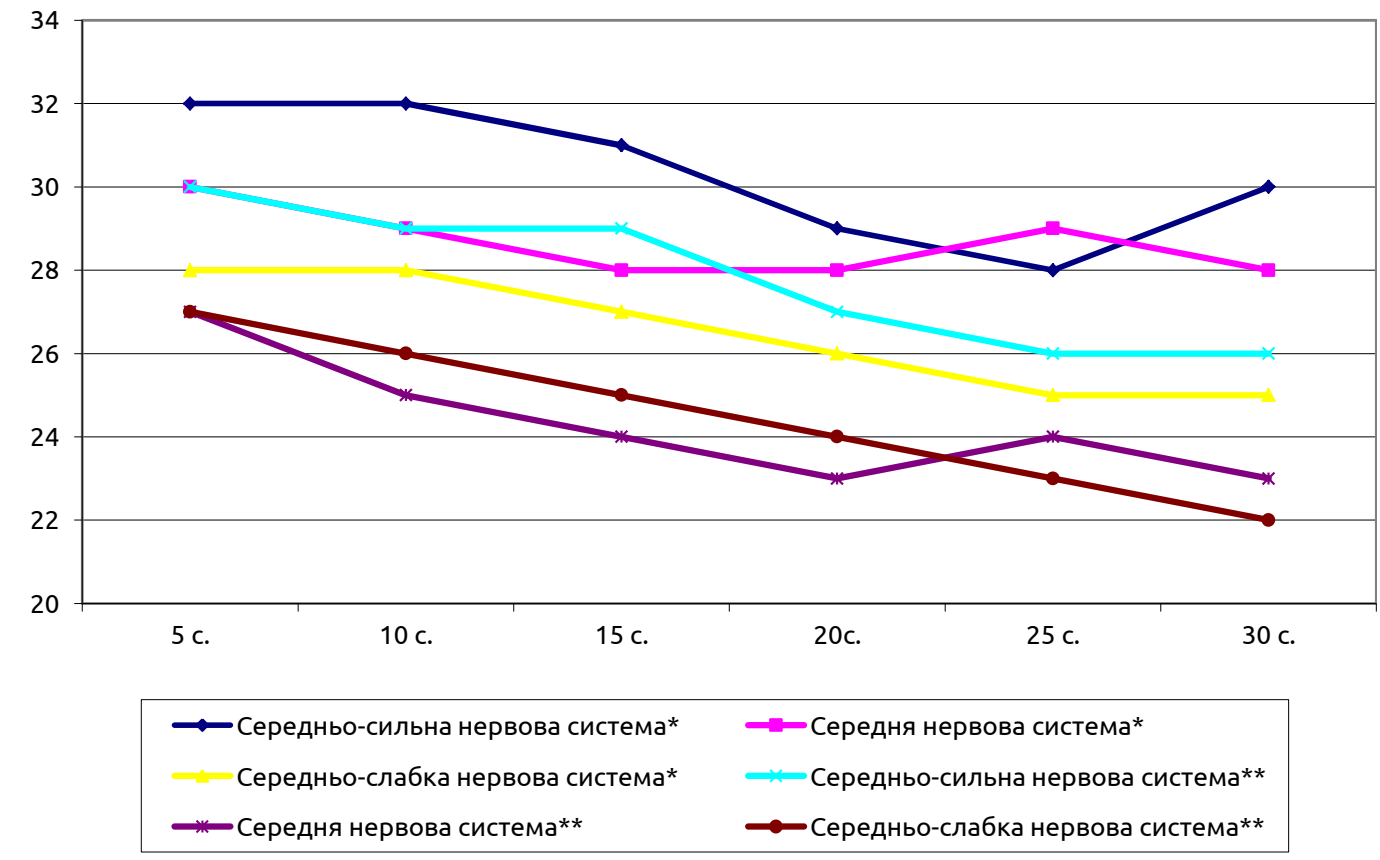

Рис. 3. Психомоторні показники в осіб з підвищеною вестибулярною чутливістю до та після вестибулярного навантаження.

Примітка. *- до навантаження, ** - після навантаження.

хів кисті утримується на одному рівні, а потім знижується. Це пояснюється тим, що робота з максимальною інтенсивністю рухів кисті викликає позамежне гальмування в нервових центрах, тому що сила нервової системи - це особливості нервових клітин великих півкуль витримувати більш або менш тривале і концентроване збудження, не переходячи в гальмівний стан [1]. 
Огляди літератури, оригінальні дослідження, погляд на проблему, випадок з практики, короткі повідомлення

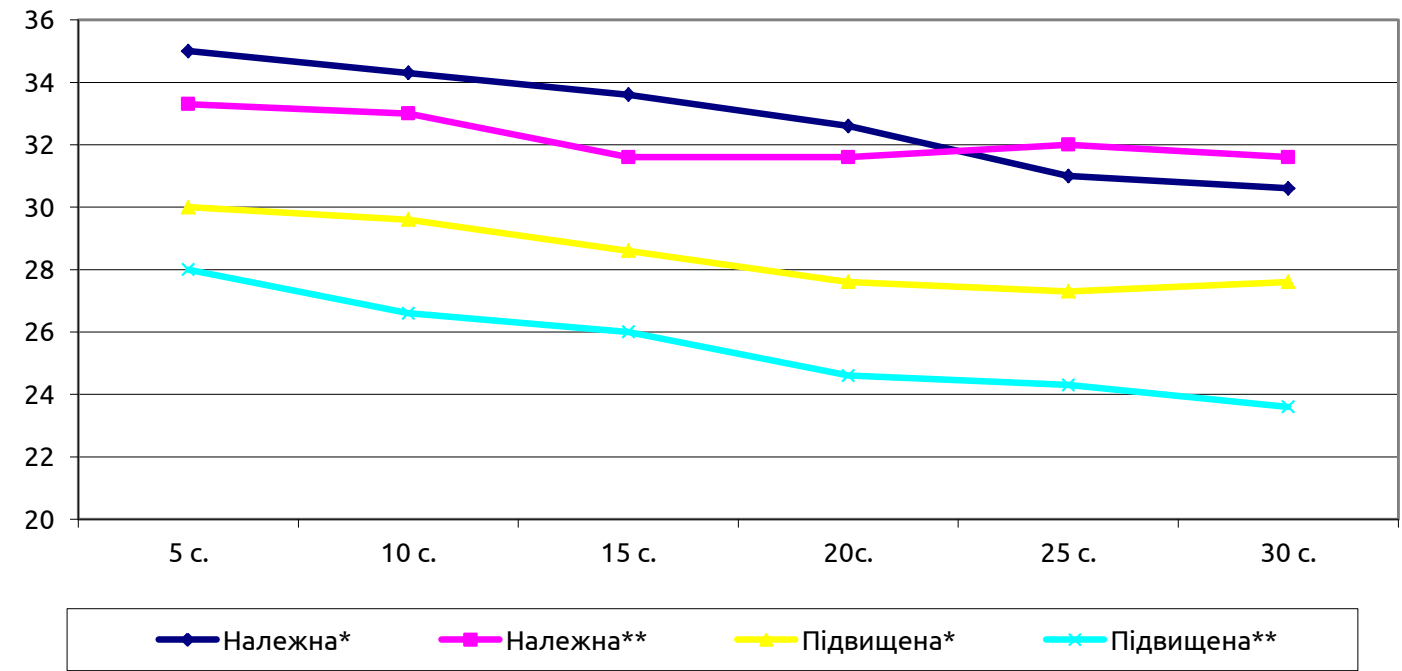

Рис. 4. Зміни психомоторних показників до та після вестибулярного навантаження залежно від вестибулярної чутливості.

Механізм зрушення рефлекторної відповіді після подразнення вестибулярного аналізатора в осіб із підвищеною вестибулярною чутливістю полягає в тому, що при обертальній навантажувальній пробі у них гальмуються імпульси, які поступають у кору головного мозку із інших аналізаторів, в основному із рухового, що призводить до спотворення м'язового диференціювання. Для таких осіб характерне зниження судинного і м'язового тонусу, що викликає швидку зміну фізичного стану і настрою. Через підвищену чутливість вестибулярного аналізатора та часте виникнення вестибулярних реакцій ці особи постійно пристосовуються до фізіологічних змін, які виникають в їх організмі. Усі ці реакції $\epsilon$ наслідком зміненої взаємодії ядер вестибулярної сенсорної системи з руховими центрами [8].

Оскільки сила нервової системи - це здатність переносити дуже сильні подразники, то ії трактують як витривалість нервової системи, яка характеризує для конкретного індивіда рівень виконання роботи, що передбачає не тільки позитивну реакцію на пропонований стимул, а й швидку послідовну зміну процесів збудження і гальмування $[1,5,6]$. Цей показник має пряме відношення до умовно-рефлекторної, поведінкової діяльності, визначає таку інтегральну характеристику мозку, як швидкість центральної обробки інформації та швидкісні параметри процесу прийняття рішення, що $є$ одним з основних чинників успішності практично будь-якої діяльності. Тому чим сильніша нервова система у людини, тим кращою вона володіє працездатністю, більшою стійкістю, витривалістю нервових клітин до сильних і тривалих подразників. Із літератури також відомо про зворотний зв'язок сили нервової системи та підвищеної чут- ливості аналізаторів, тобто особи, які мають сильну нервову систему, характеризуються низьким рівнем чутливості аналізаторів, i, навпаки, для слабкої нервової системи характерна висока чутливість $[5,9]$.

На нашу думку, отримані результати пов'язані з недостатньою фізичною активністю та діяльністю, пов'язаною з дрібною моторикою рук, які у дитячому віці забезпечують удосконалення рухових програм та адаптацію вестибулярних рецепторів до навантаження.

Методика теппінг-тесту має важливе значення в діагностиці функціонального стану центральної нервової системи [1, 5, 6, 9-11], а наші результати виявляють ознаки фізичної втоми в осіб із підвищеною вестибулярною чутливістю під впливом вестибулярного навантаження, що $є$ важливою основою для подальшої профілактики та корекції відповідних станів, а саме, для вибору оптимальних навантажень для таких осіб.

Висновки. 1. Аналіз сили нервових процесів в осіб із підвищеною чутливістю вестибулярного аналізатора показав, що значне зниження працездатності спостерігається в другій половині тесту.

2. У стані спокою відмінності психомоторних показників відображають відмінності в силі нервової системи. Результати теппінг-тесту після вестибулярного навантаження свідчать про те, що вестибулярна чутливість впливає на швидкість максимального темпу руху кисті руки та відображає зрушення в нервовій системі, викликаючи позамежне гальмування в нервових центрах.

3. Особи, які мають сильну нервову систему, характеризуються низьким рівнем чутливості аналізаторів, i, навпаки, для слабкої нервової системи характерною $є$ висока чутливість. 
Огляди літератури, оригінальні дослідження, погляд на проблему, випадок з практики, короткі повідомлення

Перпективи подальших досліджень поля-

гають у вивченні особливостей психомоторних показників в умовах подразнення вестибулярно- го аналізатора в осіб з підвищеною вестибулярною чутливістю залежно від статі.

\section{ЛІТЕРАТУРА}

1. Сімко Р. Т. Психологічні особливості вияву особистісних рис працівників патрульної поліції / Р. Т. Сімко // Проблеми сучасної психології : збірник наукових праць К-ПНУ ім. Івана Огієнка, інститут психології ім. Г. С. Костюка НАПН України. - 2016. - Вип. 34. - С. 504-512.

2. Глебов В. В. Психофизиологические особенности и процессы адаптации студентов первого курса разных факультетов РУДН / В.В.Глебов, Г. Г. Аракелов // Вестник Российского университета дружбы народов. Серия: Экология и безопасность жизнедеятельности. - 2014. № 2. - C. 89-95.

3. Вплив показників вестибулярної стійкості на рівень техніко-тактичної підготовленості баскетболісток студентської команди / І. П. Помещикова, О. О. Чек, М. В. Коваль, О. В. Кудімова // Збірник статей до ХІ Міжнародної наукової конференції «Физическое воспитание и спорт в высших учебных заведениях» (Белгород - Красноярск - Харків - Москва, 23-24 апреля 2015 г.) - С. 153-157.

4. Моісеєнко О. Визначення функціонального стану вестибулярного аналізатора волейболістів 14-15 років під впливом спеціально-спрямованих вправ / О. Mоісеєнко, Ю. Горчанюк, В. Горчанюк // Слобожанський науково-спортивний вісник - 2015. - № 2 (46). - С.133-137.

5. Бойко Г. Л. Психофізіологічні особливості студентів, які навчаються на навчальних відділеннях баскетбо- лу та волейболу / Г. Л. Бойко, Д. Н. Міщук // Молода спортивна наука України. - 2015. - № 2. - С. 35-39.

6. Малахова О. Е. Оценка и развитие координационных способностей спортсменов-дзюдоистов на первом году обучения / О. Е. Малахова, Е. Е. Пастушенко // Ученые записки университета имени П. Ф. Лесгафта 2015. - № 5 (123). - С. 125-128.

7. Вадзюк С. Н. Поширеність та прояви вестибулярної дисфункції в осіб юнацького віку / С. Н. Вадзюк, Р. М. Шмата, О. Л. Михайлюк // Вісник соціальної гігієни та організації охорони здоров'я України. - 2017. - № 1 - С. 24-28.

8. Трінус К. Ф. Кореляція запаморочень з артеріальною гіпертензією [Текст] / К. Ф. Трінус // Міжнародний неврологічний журнал. - 2015. - № 4 (74). - С. 13-19.

9. Фізіологія сенсорних систем : методичні рекомендації / І. А. Іонов, Т. Є. Комісова, В. Ф. Слюсарєв, С. О. Шаповалов. - Х. : ЧП Петров В. В., 2016. - 45 с.

10. Клименко А. І. Координаційні здібності в структурі спеціальної рухової підготовленості єдиноборців / А. І. Клименко // Проблеми фізичного виховання і спорту. - 2010. - № 3. - С. 33-35.

11. Байгужин П. А. Оптимизация оценки показателей сенсомоторной реакции - предикторов функционального состояния центральной нервной системы / П. А. Байгужин // Современные проблемы науки и образования. - 2011. - № 6. - С. 252.

\section{REFERENCES}

1. Simko, R.T. (2016). Psykholohichni osoblyvosti vyiavu osobystisnykh rys pratsivnykiv patrulnoi politsii [Psychological peculiarities of personal traits of patrol officers]. Problemy suchasnoi psykholohii: zbirnyk naukovykh prats K-PNU im. Ivana Ohiienka, instytut psykholohii im. H.S. Kostiuka NAPN Ukrainy - Problems of Modern Psychology: A Collection of Scientific works K-PNU Ivan Ogienko, Institute of Psychology. H. S. Kostyuk NAPS of Ukraine, 34, 504-512 [in Ukrainian].

2. Glebov, V.V., \& Arakelov, G.G. (2014). Psykhofiziologicheskiye osobennosti i protsessy adaptatsii studentov pervogo kursa raznykh fakultetov RUDN [Psychophysiological features and processes of adaptation of first-year students of different faculties of RUDN University]. Vestnyk Rossiyskogo universiteta druzhby narodov. Seriya: Ekologiya i bezopasnost zhyznedeyatelnosti - Bulletin of the Peoples Friendship University of Russia. Series: Ecology and Life Safety, 2, 89-95 [in Russian].

3. Pomeshchykova, I.P, Chek, O.O, Koval, M.V, \& Kudimova, O.V. (2015). Vplyv pokaznykiv vestybuliarnoi stiikosti na riven tekhniko-taktychnoi pidhotovlenosti basketbolistok studentskoi komandy [Influence of vestibular stability indicators on the level of technical and tactical preparedness of the student team basketball players]. Zbirnyk statei do XI Mizhnarodnoi naukovoi konferentsii: (Physical educa-

tion and sport in higher education) Belhorod - Krasnoiarsk Kharkiv - Moskva - Collection of articles to XI International Scientific Conference "Physical Education and Sport in Higher Educational Institutions" (Belgorod - Krasnoyarsk - Kharkiv Moscow. (pp. 153-157) [in Russian].

4. Moiseienko, O., Horchaniuk, Yu., \& Horchaniuk, V. (2015). Vyznachennia funktsionalnoho stanu vestybuliarnoho analizatora voleibolistiv $14-15$ rokiv pid vplyvom spetsialno-spriamovanykh vprav [Determination of the functional state of the vestibular analyzer volleyball players of 1415 years under the influence of specially directed exercises]. Slobozhanskyi naukovo-sportyvnyi visnyk - Slobozhanskyi Scientific and Sport Bulletin, 2, 46, 133-137 [in Ukrainian].

5. Boiko, H.L., \& Mishchuk, D.N. (2015). Psykhofiziolohichni osoblyvosti studentiv, yaki navchaiutsia na navchalnykh viddilenniakh basketbolu ta voleibolu [Psychophysiological peculiarities of students studying at basketball and volleyball training departments]. Moloda sportyvna nauka Ukrainy - Young Sports Science of Ukraine, 2, 35-39 [in Ukrainian].

6. Malakhova, O.E, \& Pastushenko, E.E. (2015). Otsenka i razvitiye koordynatsyonnykh sposobnostey sportsmenov-dzyudoistov na pervom hodu obucheniya [Assessment and development of coordination abilities of judo athletes 
Огляди літератури, оригінальні дослідження, погляд на проблему, випадок з практики, короткі повідомлення in the first year of training]. Uchenye zapiski universiteta imeni P. F. Leshafta - Scientific Notes of the University by P. F. Lesgaft, 5 (123), 125-128 [in Russian].

7. Vadziuk, S.N., Shmata, R.M, \& Mykhailiuk, O.L. (2017). Poshyrenist ta proiavy vestybuliarnoi dysfunktsii v osib yunatskoho viku [Vestibular dysfunction prevalence among addescents]. Visnyk sotsialnoi hihiieny ta orhanizatsii okhorony zdorovia Ukrainy - Bulletin of Social Hygiene and Health Protection Organization of Ukraine, 1, 24-28 [in Ukranian].

8. Trinus, K.F. (2015). Koreliatsiia zapamorochen z arterialnoiu hipertenziieiu [Dizziness correlation with hypertension]. Mizhnarodnyi nevrolohichnyi zhurnal - International Neurology Journal, 4 (74), 13-19 [in Ukrainian].

9. Ionov, I.A., Komisova, T.le, Sliusariev, V.F, \& Shapovalov, S.O. (2016). Fiziolohiia sensornykh system: metodych-

ni rekomendatsii [The physiology of sensory systems: guidelines]. Kharkiv: ChP Petrov V.V. [in Russian].

10. Klymenko, Al. (2010). Koordynatsiini zdibnosti v strukturi spetsialnoi rukhovoi pidhotovlenosti yedynobortsiv [Coordination abilities in the structure of special motor training of combatants]. Problemy fizychnoho vykhovannia i sportu - Problems of Physical Education and Sport, 3, 33-35 [in Ukrainian].

11. Baiguzhin, P.A. (2011). Optymizatsiya otsenki pokazateley sensomotornoy reaktsii - prediktorov funktsyonalnogo sostoyaniya tsentralnoy nervnoy sistemy [Optimization of the evaluation of indicators of the sensorimotor reaction - predictors of the functional state of the central nervous system]. Sovremennye problemy nauky y obrazovanyya - Modern Problems of Science and Education, 6, 252 [in Russian].

\title{
ВЛИЯНИЕ ВЕСТИБУЛЯРНОЙ НАГРУЗКИ НА ПСИХОМОТОРНЫЕ ОСОБЕННОСТИ молодых лиц
}

○С. Н. Вадзюк, Р. М. Шмата

\author{
Тернопольский национальный медицинский университет имени И. Я. Горбачевского Мз Украины
}

РЕЗЮМЕ. Психомоторные реакции и сложные интегративные взаимодействия двигательных ядер центральной нервной системы играют важную роль в обеспечении двигательной деятельности. Поэтому слаженность и упорядоченность движений во времени и пространстве широко изучаются в психофизиологии, физиологии спорта и физиологии труда. Это обусловливает чрезвычайную важность дальнейшего изучения особенностей психомоторных показателей в условиях раздражения вестибулярного анализатора у лиц с повышенной вестибулярной чувствительностью.

Цель - оценить влияние вестибулярной нагрузки на психомоторные особенности лиц с повышенной чувствительностью вестибулярного анализатора.

Материал и методы. Вестибулярную чувствительность определяли с помощью анкетирования. Психомоторные показатели определяли с помощью компьютерной системы «Диагност-1М» в режиме теппинг-теста до и после вестибулярной нагрузки. Вращательную пробу проводили на кресле Барани. Оценку силы нервных процессов проводили по классификации, предложенной Е. П. Ильиным.

Результаты. Нами установлено, что лица как с должной, так и с повышенной вестибулярной чувствительностью, имели средне-сильную, среднюю и средне-слабую нервные системы, однако среди лиц с повышенной чувствительностью в 44 \% случаев наблюдали средне-слабую нервную систему. У них после вестибулярной нагрузки максимальный темп движения кисти прямолинейно направлен на снижение. Поскольку методика теппинг-теста имеет важное значение в диагностике функционального состояния центральной нервной системы, а наши результаты обнаруживают признаки физической усталости у лиц с повышенной вестибулярной чувствительностью под влиянием вестибулярного нагрузки, то это является важной основой для дальнейшей профилактики и коррекции соответствующих состояний, а именно, для выбора оптимальных нагрузок для таких лиц.

Выводы. Анализ силы нервных процессов у лиц с повышенной чувствительностью вестибулярного анализатора показал, что значительное падение работоспособности наблюдается во второй половине теста и является следствием возникновения запредельного торможения в нервных центрах.

КЛЮЧЕВЫЕ СЛОВА: психомоторные реакции; сила нервных процессов; повышенная чувствительность; вестибулярный анализатор.

\section{INFLUENCE OF VESTIBULAR LOAD ON PSYCHOMOTOR FEATURES OF YOUNG PEOPLE}

\author{
@S. N. Vadzyuk, R. M. Shmata \\ I. Horbachevsky Ternopil National Medical University
}

SUMMARY. Psychomotor responses and complex integrative interactions of the motor nuclei of the central nervous system provide motor activity. Therefore, the orderliness of movements in time and space is widely studied in psychophysiology, physiology of sports and physiology of work. This makes it extremely important to further study the features of psychomotor indicators in the irritation of the vestibular analyzer in individuals with increased vestibular sensitivity. 
Огляди літератури, оригінальні дослідження, погляд на проблему, випадок з практики, короткі повідомлення

The aim of the study - to evaluate the influence of vestibular load on psychomotor features of persons with hypersensitivity of the vestibular analyzer.

Material and Methods. Vestibular sensitivity was determined using questionnaires. Psychomotor scores were determined using the Diagnost-1M computer system in tepping-test mode before and after vestibular loading. The rotational test was performed on a Barany chair. The assessment of the strength of nerve processes was performed according to the classification by E. P. Ilyin.

Results. We found that $44 \%$ of people with hypersensitivity were dominated by a medium-weak nervous system. In them, after vestibular loading, the maximum speed of movement of the hand decreases during the test. Since tepping testing is important for the diagnosis of the functional state of the central nervous system, and our results reveal signs of physical fatigue in people with increased vestibular sensitivity under the influence of vestibular load, this is an important basis for the further prevention and correction of appropriate conditions, and the choice of optimal conditions of such persons.

Conclusions. Analysis of the strength of nerve processes in persons with increased sensitivity of the vestibular analyzer showed that a significant drop in performance is observed in the second half of the test, which is a consequence of the occurrence of extrinsic inhibition in the nerve centers. Persons with a strong nervous system are characterized by a low level of sensitivity of the analyzers, and, conversely, a weak nervous system is characterized by high sensitivity.

KEY WORDS: psychomotor reactions; power of nervous processes; hypersensitivity; vestibular analyzer.

Отримано 10.12.1019 